\title{
FABP3 and FABP4 Genes Are the Potential Candidates for Body Weights in Korean Native Chicken
}

\author{
Muhammad Cahyadi ${ }^{1,2}$, Dongwon $\mathrm{Seo}^{1}$, Nuri $\mathrm{Choi}^{1}$, Shil Jin ${ }^{1}$, Dyah Maharani ${ }^{3}$, Kang Nyeong Heo ${ }^{4}$, \\ Bo Seok Kang ${ }^{4}$, Cheorun $\mathrm{Jo}^{1}$ and Jun Heon Lee ${ }^{1,+}$ \\ ${ }^{1}$ Department of Animal Science and Biotechnology, Chungnam National University, Daejeon 305-764, Korea \\ ${ }^{2}$ Department of Animal Science, Faculty of Agriculture, Sebelas Maret University, Surakarta 57126, Indonesia \\ ${ }^{3}$ Faculty of Animal Science, Gadjah Mada University, Yogyakarta 55281, Indonesia \\ ${ }^{4}$ Poultry Science Division, National Institute of Animal Science, RDA, Cheonan 331-801, Korea.
}

\begin{abstract}
FABPs, $15 \mathrm{kDa}$ organic substances, are small intracellular proteins which have a primary role to regulate fatty acid uptake and intracellular transport. This study was conducted to identify SNPs in the two FABP family genes and their associations with the body weight traits in Korean native chicken (KNC). Two SNPs, namely g.508C $>$ T of FABP3 gene and g.285C $>\mathrm{T}$ of FABP4 gene, have been genotyped by using PCR-RFLP method. The results showed that FABP3 was significantly associated with body weight at birth, body weights at 12 to 20 weeks, and also slaughter weight. Moreover, the g.285C $>$ T SNP of FABP4 gene was not associated with any body weight traits. These results suggested that the g.508C $>\mathrm{T}$ SNP of FABP3 genes can be used as molecular markers to select KNC having desirable body weights.
\end{abstract}

(Key words : body weight, FABP3, FABP4, Korea native chicken)

\section{INTRODUCTION}

Recently, there are increasing reputations for the native livestock breeds to the consumers including chicken. People thought that native chicken meat has better taste and meat quality than that of commercial broilers. In Korea, native chicken is preferred by Korean consumers because Korean native chicken (KNC) has less fat and better protein content, even though its price is 2 to 3 times higher than that of commercial broilers (Sang et al., 2006; Hoque et al., 2011; Seo et al., 2013). Therefore, improving both meat quality and quantity in Korean native chicken will be great challenge for poultry industry.

Few decades ago, selection of chicken was mainly based on the phenotypes. This phenotype-based selection method requires relatively long time for selection. In contrast, recent advances in molecular genetics can give some guidelines for decreasing generation intervals, which can ultimately increasing the selection intensity. Therefore, the identification and utilization of QTLs and functional candidate genes have been becoming powerful tools for faster genetic improvement in selection program by marker assisted selection (MAS) (Dekkers and Hospital, 2002).

Fatty acid-binding proteins (FABPs), members of the intracellular lipid-binding protein (iLBP) family, are small intracellular proteins that acts in fatty acid uptake regulation, metabolism, and intracellular transport by binding intracellular hydrophobic ligands and trafficking them throughout cellular compartments, including the peroxisomes, nucleus, mitochondria, and endoplasmic reticulum (Smathers and Petersen, 2011). FABP genes are known to be expressed in various types of tissue, such as muscle, adipocyte, liver, heart, brain, intestinal, testis, myelin and epidermal (Chmurzynska, 2006). Until now, at least 11 types of FABP genes have been investigated, and one of them, namely FABP11, is specifically expressed in fish (Agulleiro et al., 2007). The FABP3 gene was mainly expressed in muscle and heart. On the other hand, FABP4 gene has been particularly expressed in adipose tissues. In pigs, both FABP3 and FABP4 genes were higher expressed in subcutaneous adipocyte tissue than

\footnotetext{
${ }^{\dagger}$ To whom correspondence should be addressed : junheon@cnu.ac.kr
} 
intramuscular adipocyte tissue during growing time (Gardan et al., 2007). In addition, expression of both FABP3 and FABP4 genes was also increased in longissimus dorsi (LD) tissue during growing. Particularly, level of FABP4 mRNA expression was positively correlated with intramuscular fat (IMF) content and body weight in pigs (Cho et al., 2011; Chen et al., 2013). In the case of mice, level of FABP3 protein can significantly increase body weight and other metabolic traits which was suggested that expression of FABP3 was correlated with obesity and insulin resistance (Kusudo et al., 2011). Also, polymorphisms in both FABP3 and FABP4 genes were tightly linked with fat-related traits in chicken (Wang et al., 2006; Li et al., 2008; Wang et al., 2009; Ye et al., 2010). Furthermore, variations within FABP4 gene were associated with slaughter and meat quality traits, especially living weight, carcass weight, breast muscle weight, abdominal fat weight, and abdominal fat percentage (You et al., 2009). Therefore, in this study, we investigated variations in FABP3 and FABP4 genes and their relationships with body weight traits in Korean native chicken.

\section{MATERIALS AND METHODS}

\section{Chicken Population and DNA Isolation}

Two populations used in this experiment were consisted by 15 sires and 73 dams $\left(F_{0}\right)$, and $590 F_{1}$ birds comprised by $110,90,125,131$, and 134 offspring from gray, black, white, yellow-brown, and red-brown lines of $\mathrm{KNC}$, respectively. The five lines of $\mathrm{KNC}$ were distinguished on the basis of feather colors (Hoque et al., 2012). These animals were reared under the standard breeding procedures in National Institute of Animal Sciences (NIAS), Korea. The data including body weight at birth (BBW), body weight at 2 to 20 weeks of age, and slaughter weight (SW) were recorded every two weeks. In addition, their blood samples were collected from wing veins by using vacutainer tubes containing EDTA. These blood samples were used to extract DNA based on Miller et al. (1988) methods. The isolated DNA was maintained in refrigerator at $-20^{\circ} \mathrm{C}$ for further analysis.

\section{PCR Condition and Genotyping}

Two pairs of primers, one for FABP3 gene and another for FABP4 gene, were designed based on Maharani et al. (2011). The primer and restriction enzyme information are shown in Table 1. Polymerase chain reaction was carried out in $20 \mu \mathrm{L}$ volume containing $50 \mathrm{ng}$ per $\mu \mathrm{L}$ DNA genome, primers, 10 $\mathrm{mM}$ dNTP, $10 \times$ reaction buffer, HS Taq Polymerase (GenetBio, Korea), and distilled water. The PCR conditions were as follows: $94^{\circ} \mathrm{C}$ for 10 minutes for pre-denaturation, 35 cycles of $94^{\circ} \mathrm{C}$ for 30 seconds, $58^{\circ} \mathrm{C}$ for 30 seconds, and $72^{\circ} \mathrm{C}$ for 30 seconds, and followed by 10 minutes of final extension at $72^{\circ} \mathrm{C}$. Reaction was performed using either GeneAmp PCR system 2700 (Applied Biosystems, USA) or $\mathrm{C} 1000^{\mathrm{TM}}$ Thermal Cycler (BioRad, USA). The PCR products were visualized by $2 \%$ standard agarose gels stained with ethidium bromide (GenetBio, Korea). For genotyping, PCR restriction fragment length polymorphism (RFLP) was applied. Approximately, $15 \mu \mathrm{L}$ of PCR product was digested with 2 units of each restriction enzyme (Table 1) based on the protocol recommended by company (Biolabs ${ }^{\circledR}$ Inc., New England). After that, the digested PCR product was separated on 3\% agarose gels to identify genotype variations.

\section{Statistical Analysis}

Genotype and allele frequencies were measured, and Pearson's Chi-square test was applied to verify the Hardy-Wein-

Table 1. Primers for PCR amplification and SNP identification in FABP3 and FABP4 genes

\begin{tabular}{|c|c|c|c|c|c|}
\hline Gene/SNP & $\begin{array}{c}\text { GenBank } \\
\text { accession No. }\end{array}$ & $\begin{array}{l}\text { Sequence } \\
\left(5^{\prime} \text { to } 3^{\prime}\right)\end{array}$ & $\begin{array}{l}\text { PCR product size } \\
\text { (bp) }\end{array}$ & $\begin{array}{l}\text { Annealing temperature } \\
\left({ }^{\circ} \mathrm{C}\right)\end{array}$ & $\begin{array}{c}\text { Restriction } \\
\text { enzyme }\end{array}$ \\
\hline $\begin{array}{l}\text { FABP3/ } \\
\text { g. } 508 \mathrm{C}>\mathrm{T}\end{array}$ & NC_006110 & $\begin{array}{l}\text { F: ggtgatgcatgaggacattg } \\
\text { R: actaccgccttgctcacact }\end{array}$ & 460 & 58 & NlaIII \\
\hline $\begin{array}{l}\text { FABP4/ } \\
\text { g. } 285 \mathrm{C}>\mathrm{T}\end{array}$ & NC_006089 & $\begin{array}{l}\text { F: tgtgacctactggcaaagga } \\
\text { R: ttcctcccagtcaagctttc }\end{array}$ & 477 & 58 & TaqI \\
\hline
\end{tabular}


berg equilibrium status. The effects of FABP genes variations on body weight traits were analyzed by using general linear model (GLM) procedure in the MINITAB version 14.0 software (Minitab Inc., USA). The following model was used for association analysis between the genotype and body weight:

$$
\mathrm{Y}_{\mathrm{ijk} k m n o}=\mu+\mathrm{G}_{\mathrm{i}}+\mathrm{S}_{\mathrm{j}}+\mathrm{B}_{\mathrm{k}}+\mathrm{L}_{\mathrm{l}}+\mathrm{F}_{\mathrm{m}(\mathrm{l})}+\mathrm{M}_{\mathrm{n}(\mathrm{Im})}+\varepsilon_{\mathrm{ijk} k m n o}
$$

Where, $Y_{\mathrm{ijk} k m n o}$ is the phenotype of the $o^{\text {th }}$ animal, $\mu$ is population mean, $G_{i}$ is the fixed effect of genotype, $S_{j}$ is the fixed effect of sex, $B_{k}$ is the fixed effect of batch, $L_{l}$ is the fixed effect of line, $F_{m(1)}$ is the random effect of the $m^{\text {th }}$ sire nested within the $1^{\text {th }}$ line, $\mathrm{M}_{\mathrm{n}(\mathrm{m})}$ is the random effect of the $\mathrm{n}^{\text {th }}$ dam nested within the $\mathrm{t}^{\text {th }}$ line and $\mathrm{m}^{\text {th }}$ sire, and $\varepsilon_{\mathrm{ijk} k \mathrm{mno}}$ is the residual error associated with the $\mathrm{o}^{\text {th }}$ animal. In order to test the pairwise differences between the genotypes, Tukey's test was also performed.

\section{RESULTS}

\section{Genotype and Allele Frequencies}

Three genotypes were identified in both FABP3 and FABP4 genes. In case of g.508C $>\mathrm{T}$ SNP in FABP3 gene, four DNA fragments, namely $201 \mathrm{bp}, 176 \mathrm{bp}, 72 \mathrm{bp}$ and 11 $\mathrm{bp}$, were found in animals having CC genotypes, whereas five DNA fragments, $201 \mathrm{bp}, 140 \mathrm{bp}, 72 \mathrm{bp}, 36 \mathrm{bp}$ and 11 bp, were found in animals having TT genotypes (Fig. 1A). On the other hand, the g.285C $>$ T SNP in FABP4 gene was clearly

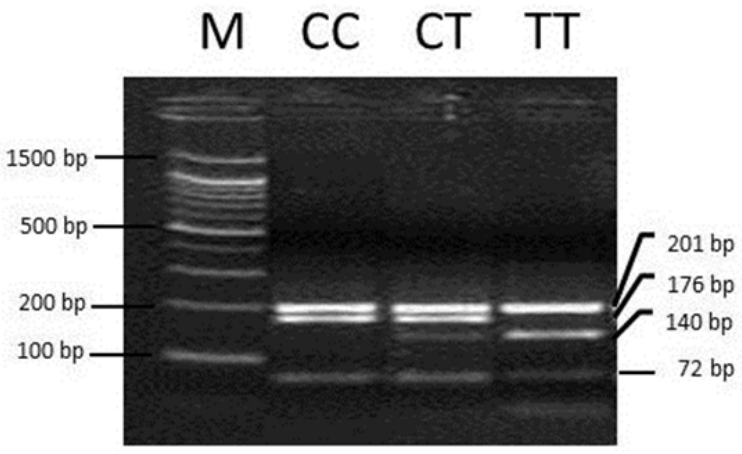

(A)

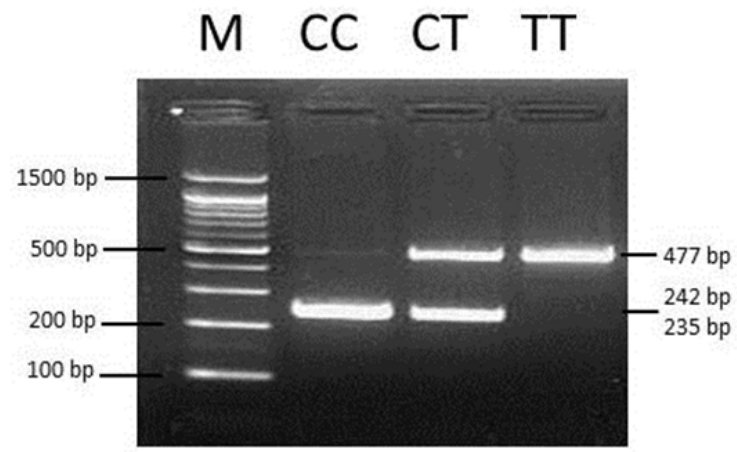

(B)

Fig. 1. Genotypes of g.508C $>$ T SNP of FABP3 gene (A) and g.285C $>$ T SNP of FABP4 gene (B) visualized by $3 \%$ agarose gel electrophoresis

distinguished using 3\% agarose gels. The 477 bp of PCR product was separated into $242 \mathrm{bp}$ and $235 \mathrm{bp}$ fragments for animals having $\mathrm{CC}$ genotypes (Fig. 1B). It should be noted that DNA fragments under $50 \mathrm{bp}$ could not be identified in agarose gel with bare eyes.

Table 2. Genotype and allele frequencies of g.508C $>\mathrm{T}$ SNP of FABP3 gene and g.285C $>\mathrm{T}$ SNP of FABP4 gene in Korean native chicken

\begin{tabular}{|c|c|c|c|c|c|c|}
\hline \multirow{3}{*}{ Generation } & \multicolumn{3}{|c|}{ Genotype frequency (Number of animal) } & \multicolumn{2}{|c|}{ Allele frequency } & \multirow{3}{*}{$\begin{array}{c}\chi^{2} \\
(P \text {-value })\end{array}$} \\
\hline & \multicolumn{3}{|l|}{ g. $508 \mathrm{C}>\mathrm{T}$} & \multirow[b]{2}{*}{$\mathrm{C}$} & \multirow[b]{2}{*}{$\mathrm{T}$} & \\
\hline & $\mathrm{CC}$ & $\mathrm{CT}$ & $\mathrm{TT}$ & & & \\
\hline Parents & $0.49(43)$ & $0.40(35)$ & $0.11(10)$ & 0.69 & 0.31 & $0.49(0.484)$ \\
\hline \multirow[t]{3}{*}{$\mathrm{F}_{1}$} & $0.52(309)$ & $0.41(242)$ & $0.07(39)$ & 0.73 & 0.27 & $0.84(0.359)$ \\
\hline & \multicolumn{3}{|l|}{ g. $285 \mathrm{C}>\mathrm{T}$} & & & \multirow{2}{*}{$\begin{array}{c}\chi^{2} \\
(P \text {-value })\end{array}$} \\
\hline & $\mathrm{CC}$ & $\mathrm{CT}$ & TT & $\mathrm{C}$ & $\mathrm{T}$ & \\
\hline Parents & $0.11(10)$ & $0.38(33)$ & $0.51(45)$ & 0.30 & 0.70 & $1.05(0.306)$ \\
\hline $\mathrm{F}_{1}$ & $0.10(61)$ & $0.33(197)$ & $0.56(332)$ & 0.27 & 0.73 & $13.93(0.0002)$ \\
\hline
\end{tabular}


Either parent or $F_{1}$ population was in Hardy-Weinberg equilibrium (HWE) for g.508C $>\mathrm{T}$ SNP. Different HWE status was identified for the g.285C $>$ T SNP in FABP4 gene, whereas parent population was in HWE. On the other hand, $F_{1}$ population was not in HWE (Table 2). It may be due to selective pressure for desirable phenotypic traits, and inbreeding in Korean native chicken (Falconer and Mackay, 1996; Heo et al., 2011).

\section{Association of SNPs in FABP Genes with Body Weight Traits}

Twelve body weight-related traits, including body weight at birth, body weights at 2 to 20 weeks of age, and slaughter weight, were used for association analysis. Both sex and line effects were tested in this study. The results showed that either sex or chicken line was affecting body weights in Korean native chicken. Body weights in red-brown and black lines were significantly higher than other lines in all ages. In addition, both dam and sire were strongly affecting body weight in $\mathrm{KNC}$ (data not shown).
The allele substitution of $\mathrm{g} .508 \mathrm{C}>\mathrm{T}$ in intron 2 region of FABP3 gene was associated with body weights (Table 3). Particularly, this SNP was associated with body weight at birth, body weight at 12 to 20 weeks of age, and slaughter weight. In addition, it was also suggestively correlated with body weights at 4 to 10 weeks of age $(P<0.15)$. Chickens having TT genotypes were higher in body weight at 2 weeks of age. On the other hand, chickens with $\mathrm{CC}$ genotypes were higher in body weights at 12 to 20 weeks of age and slaughter weight. In addition, these results revealed that chickens having $\mathrm{C}$ alleles were consistently having higher body weights compare to chickens having $\mathrm{T}$ alleles in growing to finishing periods. In contrast, g.285C $>\mathrm{T}$ SNP in FABP4 gene was not associated with any body weight traits.

\section{DISCUSSION}

Previous reports suggested that family of FABP gene members were tightly linked with fatness traits, especially intra-

Table 3. Association between g.508C $>\mathrm{T}$ SNP of FABP3 gene and g.285C $>$ T SNP of FABP4 gene with body weight traits in Korean native chicken

\begin{tabular}{|c|c|c|c|c|c|c|c|c|}
\hline \multirow{2}{*}{ Traits } & \multicolumn{3}{|c|}{ g. $508 \mathrm{C}>\mathrm{T} \quad \mathrm{SNP}$} & \multirow{2}{*}{$P$-value } & \multicolumn{3}{|c|}{ g. $285 \mathrm{C}>\mathrm{T}$ SNP } & \multirow{2}{*}{$P$-value } \\
\hline & CC (309) & CT (242) & TT (39) & & CC (61) & CT (197) & TT (332) & \\
\hline BBW (g) & $38.45 \pm 0.20^{\mathrm{a}}$ & $38.62 \pm 0.22^{\mathrm{a}}$ & $39.94 \pm 0.49^{b}$ & 0.019 & $38.64 \pm 0.40$ & $38.79 \pm 0.23$ & $38.51 \pm 0.20$ & 0.631 \\
\hline BW2 (g) & $147.91 \pm 1.92$ & $141.92 \pm 2.06$ & $139.46 \pm 4.63$ & 0.057 & $140.30 \pm 3.73$ & $145.15 \pm 2.20$ & $145.53 \pm 1.89$ & 0.401 \\
\hline BW4 (g) & $277.75 \pm 5.44$ & $262.16 \pm 5.86$ & $254.65 \pm 13.16$ & 0.084 & $253.14 \pm 10.58$ & $268.86 \pm 6.24$ & $273.34 \pm 5.36$ & 0.237 \\
\hline BW6 (g) & $444.35 \pm 10.16$ & $420.00 \pm 10.93$ & $395.91 \pm 24.58$ & 0.105 & $400.94 \pm 19.75$ & $433.43 \pm 11.64$ & $435.13 \pm 10.00$ & 0.237 \\
\hline BW8 (g) & $631.99 \pm 15.54$ & $595.77 \pm 16.72$ & $567.80 \pm 37.59$ & 0.150 & $583.17 \pm 30.21$ & $622.85 \pm 17.80$ & $611.98 \pm 15.30$ & 0.403 \\
\hline BW10 (g) & $787.30 \pm 16.95$ & $752.57 \pm 18.24$ & $706.09 \pm 41.00$ & 0.134 & $737.32 \pm 32.94$ & $784.23 \pm 19.41$ & $762.94 \pm 16.68$ & 0.293 \\
\hline BW12 (g) & $1,028.10 \pm 20.11^{\mathrm{a}}$ & $970.62 \pm 21.63^{\mathrm{ab}}$ & $915.02 \pm 48.64^{\mathrm{b}}$ & 0.042 & $947.60 \pm 39.19$ & $1,002.50 \pm 23.09$ & $1,002.32 \pm 19.85$ & 0.362 \\
\hline BW14 (g) & $1,215.11 \pm 19.69^{\mathrm{a}}$ & $1,154.82 \pm 21.18^{\mathrm{ab}}$ & $1,071.70 \pm 47.62^{\mathrm{b}}$ & 0.010 & $1,141.61 \pm 38.49$ & $1,189.89 \pm 22.68$ & $1,182.18 \pm 19.49$ & 0.451 \\
\hline BW16 (g) & $1,407.95 \pm 21.51^{\mathrm{a}}$ & $1,356.13 \pm 23.13^{\mathrm{ab}}$ & $1,269.92 \pm 52.01^{\mathrm{b}}$ & 0.035 & $1,334.49 \pm 41.94$ & $1,386.13 \pm 24.71$ & $1,379.89 \pm 21.24$ & 0.465 \\
\hline BW18 (g) & $1,602.94 \pm 18.63^{\mathrm{a}}$ & $1,566.15 \pm 20.03^{a b}$ & $1,465.46 \pm 45.04^{\mathrm{b}}$ & 0.018 & $1,541.91 \pm 36.34$ & $1,593.05 \pm 21.41$ & $1,576.63 \pm 18.40$ & 0.342 \\
\hline BW20 (g) & $1,796.83 \pm 19.22^{\mathrm{a}}$ & $1,756.62 \pm 20.67^{\mathrm{ab}}$ & $1,673.46 \pm 46.48^{\mathrm{b}}$ & 0.042 & $1,743.14 \pm 37.46$ & $1,788.49 \pm 22.07$ & $1,767.32 \pm 18.97$ & 0.407 \\
\hline SW (g) & $1,707.16 \pm 19.09^{\mathrm{a}}$ & $1,665.54 \pm 20.53^{\mathrm{ab}}$ & $1,574.69 \pm 46.15^{\mathrm{b}}$ & 0.026 & $1,658.95 \pm 37.24$ & $1,696.14 \pm 21.95$ & $1,676.16 \pm 18.86$ & 0.517 \\
\hline
\end{tabular}

Values in table represent Least Squares Mean $(\mathrm{LSM}) \pm \mathrm{SE}$.

Abbreviation: BBW: birth body weight; BW2, BW4, BW6, BW8, BW10, BW12, BW14, BW16, BW18, BW20: body weight at 2 to 20 weeks of age; SW: slaughter weight.

a,ab,b Subscript in the same row showed significant effects between subject $(P<0.05)$. 
muscular fat content in chicken (Wang et al., 2007; Wang et al., 2009; Li et al., 2010; Ye et al., 2010). Among the FABP gene member, adipose fatty acids binding protein (FABP4) and heart-muscle fatty acid binding protein (FABP3) genes were the potential candidate genes for fat-related traits. In human, FABP4 gene has been reported to have the relationships with obesity and metabolic syndrome. Decreasing expression of FABP4 gene has been significantly demoting both body weight status and fat mass index in obese adult and children (Reinehr et al., 2007; Engl et al., 2008; Corripio et al., 2010; Khalyfa et al., 2010). Furthermore, FABP4 genes have also been affecting body weight and IMF in pig, whereas high level of FABP3 expression was linked with obesity in mice and human (Cho et al., 2011; Kusudo et al., 2011; Chen et al., 2013). Therefore, we hypothesized that polymorphisms of both FABP3 and FABP4 genes may be associated with body weight traits in Korean native chicken.

Body weight is one of growth-related traits which have achieved great progress in the broiler breeding program recently (Ikeobi et al., 2004; Bai et al., 2012). These body weight traits directly affect economic values of poultry products (Nassar et al., 2012). In present study, two single polymorphisms (SNPs), an SNP in intron region of FABP3 gene and an SNP in exon 1 region of FABP4 gene, were tested as potential candidate markers for body weight in Korean native chicken. As the results, an SNP in FABP3 gene was significantly associated with body weight at 2 weeks, and at the end stage of age in $\mathrm{KNC}$, while a SNP in FABP4 was not associated with any body weight traits. In conclusion, g.508C $>\mathrm{T}$ SNP in FABP3 gene have significant effects with body weight traits, and it can be used as molecular markers to select desired body weights in $\mathrm{KNC}$.

\section{ACKNOWLEDGEMENT}

This study was carried out with the support of "FTA Agriculture Research Project (Project No. PJ9070112013)", RDA, Republic of Korea.

\section{REFERENCES}

Agulleiro MJ, Andre M, Morais S, Cerda J, Babin PJ 2007
High transcript level of fatty acid-binding protein 11 but not of very low-density lipoprotein receptor is correlated to ovarian follicle atresia in a teleost fish (Solea senegalensis). Biol Reprod 77:504-516.

Bai Y, Sun G, Kang X, Han R, Tian Y, Li H, Wei Y, Zhu S 2012 Polymorphisms of the pro-opiomelanocortin and agouti-related protein genes and their association with chicken production traits. Mol Biol Rep 39:7533-7539.

Chen QM, Wang H, Zeng YQ, Chen W 2013 Developmental changes and effect on intramuscular fat content of $\mathrm{H}$ FABP and A-FABP mRNA expression in pigs. J Appl Genet 54:119-123.

Chmurzynska A 2006 The multigene family of fatty acidbinding proteins (FABPs): function, structure and polymorphism. J Appl Genet 47:39-48.

Cho KH, Kim MJ, Jeon GJ, Chung HY 2011 Association of genetic variants for FABP3 gene with back fat thickness and intramuscular fat content in pig. Mol Biol Rep 38: 2161-2166.

Corripio R, Gonzalez-Clemente JM, Perez-Sanchez J, Naf S, Gallart L, Nosas R, Vendrell J, Caixas A 2010 Weight loss in prepubertal obese children is associated with a decrease in adipocyte fatty-acid-binding protein without changes in lipocalin-2: a 2-year longitudinal study. Eur J Endocrinol 163:887-893.

Dekkers JCM, Hospital F 2002 The use of molecular genetics in the improvement of agricultural populations. Nat Rev Genet 3:22-32.

Engl J, Ciardi C, Tatarczyk T, Kaser S, Laimer M, Laimer E, Weiss H, Aigner F, Molnar C, Tilg H, Patsch JR, Ebenbichler CF 2008 A-FABP-a biomarker associated with the metabolic syndrome and/or an indicator of weight change? Obesity (Silver Spring) 16:1838-1842.

Falconer DS, Mackay TFC 1996 Introduction of Quantitative Genetics. 4th ed. Longman, Malaysia.

Gardan D, Louveau I, Gondret F 2007 Adipocyte- and heart-type fatty acid binding proteins are both expressed in subcutaneous and intramuscular porcine Sus scrofa adipocytes. Comp Biochem Physiol B Biochem Mol Biol 148:14-19.

Heo KN, Choo HJ, Seo BY, Park MN, Jung KC, Hwangbo J, Kim HK, Hong EC, Seo OS, Kang BS 2011 Inves- 
tigation of TYR and MC1R polymorphisms in Korean native chicken and commercial chickens. CNU J Agric Sci 38:465-471.

Hoque MR, Lee SH, Jung KC, Kang BS, Park MN, Lim HK, Choi KD, Lee JH 2011 Discrimination of Korean native chicken populations using SNPs from mtDNA and MHC polymorphisms. Asian-Aust J Anim Sci 24:1637-1643.

Hoque MR, Lee SW, Lee JH 2012 DNA markers in chicken for breed discrimination. CNU J Agric Sci 39:208-214.

Ikeobi CON, Woolliams JA, Morrice DR, Law A, Windsor D, Burt DW, Hocking PM 2004 Quantitative trait loci for meat yield and muscle distribution in a broiler layer cross. Livestock Prod Sci 87:143-151.

Khalyfa A, Bhushan B, Hegazi M, Kim J, Kheirandish-Gozal L, Bhattacharjee R, Capdevila OS, Gozal D 2010 Fattyacid binding protein 4 gene variants and childhood obesity: Potential implications for insulin sensitivity and CRP levels. Lipids Health Dis 9:18-23.

Kusudo T, Kontani Y, Kataoka N, Ando F, Shimokata H, Yamashita H 2011 Fatty acid-binding protein 3 stimulates glucose uptake by facilitating AS160 phosphorylation in mouse muscle cells. Genes Cells 16: 681-691.

Li H, Wu G, Zhang J, Yang N 2010 Identification of the heart-type fatty acid-binding protein as a major gene for chicken fatty acid metabolism by Bayesian network analysis. Poultry Sci 89:8925-1833.

Li WJ, Li HB, Chen JL, Zhao GP, Zheng MQ, Wen J 2008 Gene expression of heart- and adipocyte-fatty acid-binding protein and correlation with intramuscular fat in Chinese chickens. Anim Biotechnol 19:189-193.

Maharani D, Park HB, Jung Y, Jung S, Jo C, Lee JH 2011 Investigation of SNPs in FABP3 and FABP4 genes and their possible relationships with fatty acid composition in broiler. Korean J Poult Sci 38:231-237.

Miller SA, Dykes DD, Polesky HF 1988 A simple salting out procedure for extracting DNA from human nucleated cells. Nucleic Acids Res 16:1215.

Nassar MK, Goraga ZS, Brockmann GA 2012 Quantitative trait loci segregating in crosses between New Hampshire and White Leghorn chicken lines: II. Muscle weight and carcass composition. Anim Genet 43:739-745.

Reinehr T, Stoffel-Wagner B, Roth CL 2007 Adipocyte fatty acid-binding protein in obese children before and after weight loss. Metabolism 56:1735-1741.

Sang BD, Hong SK, Kim HK, Choi CH, Kim SD, Cho YM, Sang BC, Lee JH, Jeon GJ, Lee HK 2006 Estimation of genetic parameters for economic traits in Korean native chickens. Asian-Aust J Anim Sci 19:319-323.

Seo DW, Hoque MR, Choi NR, Sultana H, Park HB, Neo KN, Kang BS, Lim HT, Lee SH, Jo C, Lee JH 2013 Discrimination of Korean native chicken lines using fifteen selected microsatellite markers. Asian-Aust J Anim Sci 26:316-322.

Smathers RL, Petersen DR 2011 The human fatty acidbinding protein family: evolutionary divergences and functions. Human Genomics 5:170-191.

Wang Q, Guan T, Li H, Bernlohr DA 2009 A novel polymorphism in the chicken adipocyte fatty acid-binding protein gene (FABP4) that alters ligand-binding and correlates with fatness. Comp Biochem Physiol B Biochem Mol Biol 154:298-302.

Wang Q, Li H, Leng L, Wang Y, Tang Z, Li N, Zhang F 2007 Polymorphism of heart fatty acid-binding protein gene associatied with fatness traits in the chicken. Anim Biotechnol 18:91-99.

Wang Q, Li H, Li N, Leng L, Wang Y, Tang Z 2006 Identification of single nucleotide polymorphism of adipocyte fatty acid-binding protein gene and its association with fatness traits in the chicken. Poultry Sci 85:429-434.

Ye MH, Chen JL, Zhao GP, Zheng MQ, Wen J 2010 Associations of A-FABP and H-FABP markers with the content of intramuscular fat in Beijing-You chicken. Anim Biotechnol 21:14-24.

You X, Liu Y, Jiang X, Du H, Liu Z, Zhu Q 2009 Relationships between single nucleotide polymorphisms of the H-FABP gene and slaughter and meat quality traits in chicken. Biochem Genet 47:511-520.

(접수: 2013. 3. 12, 수정: 2013. 5. 7, 채택: 2013. 5. 7) 